UDC 81'25:81'373=111

DOI https://doi.org/10.32841/2409-1154.2021.47-3.44

\author{
Yukhymets S. Yu., \\ Candidate of Pedagogical Sciences, Associate Professor, \\ Associate Professor at the Department of Philology \\ Odesa National Maritime University
}

\title{
THE PECULIARITIES OF TRANSLATING ENGLISH ADVERTISING TOURIST TEXTS INTO UKRAINIAN
}

Summary. The article dwells upon the peculiarities of English advertising tourist texts in the translational aspect as opposed to other types of advertisement texts and tourist texts in general as well. The article reveals the nature of tourist discourse and outlines the distinctive features of tourist texts.

The results of the study showed that tourism discourse is a subtype of advertising discourse, which contains a number of universal characteristics inherent in texts written in such diverse languages as English and Ukrainian. Among such characteristics are: the use of the imperative mood, comparative and superlative degrees of comparison of adjectives, the choice of emotionally colored, positive vocabulary in order to influence the potential consumer of travel services. It has been concluded that the density of tourist texts fully correspondences with the degree of specialization of a text and makes its translation more complicated. The text, intended for tourism specialists can be completely vague and unclear for common tourists. Thus, the strategy of re-addressing and the tactic of linguisticcultural adaptation are employed to neutralize tourist texts with high level of term density when translating for the tourist, whereas professional-oriented target texts retain the high level of term density if compared to the source text. In general, therefore, it seems that the quality of tourism translation is largely influenced by the means of translating tourism terminology. Abbreviations in tourism texts and strategies for their translation need further investigations outside this paper.

The paper gives the comprehensive review of means and ways of tourism terminology translation. The detailed analysis of the strategies, tactics and operations of translating English advertising tourist texts into Ukrainian is also provided. The perspective is seen in creating the universal standards for adequate translation discourse translation.

Key words: advertising tourist texts, tourist discourse, strategy, distinctive features, terminology.

Introduction. Nowadays there is rapid growth and expansion of the tourism field which has been one of the leading factors of economic boost. The number of tourists is increasing year after year. The tourism discourse has recently become the object of numerous researches in economy, sociology, politics and linguistics.

Theoretical grounding has been formed by the works by Ye.V. Zaiukova [1], S.A. Korolkova [2], A.A. Novozhylova [2], A.M. Sheyko [2], N.H. Nikitina [3], N.A. Tiuleneva [4], N.V. Filatova [5], A.O. Tsyrempilon [6; 7], T.V. Platitsyna [6], T.A. Yudina [8], M.T. Cabré [9], G.M.S. Dann [10], P. Newmark [11], P. Pierini [12], H. Sanning [13], C. Taylor [14].

P. Newmark [11] has focused mainly on the research of tourism discourse translation in economy, P. Pierini [12] has contributed greatly to the methodology of on-line tourist texts translation.
The object of the current research is represented by English advertising tourist texts and their Ukrainian translations. The subject of the research are peculiarities of translating English advertising tourist texts into Ukrainian.

The urgency of the research is predetermined by the increasing relevance of tourism in economy as a means of economic growth and the linguistic peculiarities of tourism discourse. The novelty of the research is in an attempt to work out the most efficient strategies, tactics and operations of translating advertising tourist texts in particular into the Ukrainian language taking into account the typological discrepancy of both lexical and grammatical features in the translation language pair.

In contrast to H. Sanning's works [13], focused on the neutralizing translation as the only possible one for rendering tourist texts as such, our research is aimed at scrutinizing the efficiency of different translation strategies recently discovered and formulated by the representatives of the communicative-functional approach to translation studies.

The objective and tasks of the research. The objective is seen in outlining the distinctive features of advertising tourist texts, relying on the findings of the recent works in this field both on the basis of the English and Ukrainian languages.

In accordance with the objective the corresponding tasks has been formulated: to give a definition of advertising tourist texts; to outline the key peculiarities of advertising tourist texts; to select and analyze the most appropriate strategies, tactics and techniques of translating advertising tourist texts.

Research materials and methods. The following research methods have been employed with regards to the objective, subject, object and tasks of the research: the method of theoretical generalization employed to form the grounding for the research; comparative method to contrast English texts and their Ukrainian translations; the method of analysis to describe advertising tourist texts in the two languages under investigation. The research was carried out on the basis of the website www.tripadvisor.com.ua.

Results and discussion. Advertisement is a complex phenomenon which has many various aspects. Two main advertisement conceptions are outlined today: the cultural or historically cultural one and the marketing or specifically pragmatic one.

The most complete approach is the one allowing to combine both conceptions and as a result reflecting the economic, marketing and cultural peculiarities of advertisement.

Many researchers define advertising texts as forms of specific promotion of goods, ideas or services aimed at manipulating potential customers and affecting their attitudes and preferences.

Advertisement is not just an announcement, it's also a means of attraction, creation of an image. 
Advertising is aimed at forming the stereotypes of ways of life, thinking, morals and morality as important constituents of consciousness formation [2, p. 141].

As it follows from the definition given above general communicative tasks and specific pragmatic setting characterize functional and stylistic status of an advertising text and the specificity of its semantics.

Advertising texts are grounded upon trustworthy information about the advertized object, its difference from others of the samekind and possible commercial profit. However, despite its persuasiveness, the content of an advertising text must be exciting and what's even more important not explicitly manipulating. Copywriters should aspire to make advertising texts sound businesslike, convincing, understandable and properly oriented. As follows, the semantics of an advertising texts is synthesized by the two principles the logical and the emotional one.

In this sense there is certain similarity between the information presentation strategy in a belles-lettres text and in an advertising text. On one hand, advertising texts are distinguished by logicality, preciseness, brevity, transparence of meaning based upon argumentation, on the other hand - imagery, subjectivity, representing the author's attitude to the advertised product and simultaneously affecting the customer's mind and emotions thus encouraging him/her to purchase the given product.

The notion of touristic discourse has been so thoroughly studied recently that there have been worked out specific algorithms for translating touristic texts. According to the conception of touristic texts translation algorithms the following six stages of touristic texts processing are distinguished:

- data collection;

- account of informational value;

- account of accessibility;

- account of stimulation principle;

- account of expressiveness principle;

- stage of post-translation analysis.

The first and the last of the above registered stages are mandatory in translating any type of discourse while such features as high informational value, accessibility, stimulation and expressiveness are peculiar for touristic texts and essential for touristic discourse outline in general. The latter also reflect the distinctive features of advertising texts thus witnessing that touristic discourse is a subtype of advertising discourse.

The necessity of the knowledge of advertising touristic texts translation algorithms is confirmed by the experience of translating specific sites oriented at the target audience of tourists. As it has become evident from the recent researches on hotels' sites translations translators often make use of word-for-word translation and create calques.

The doubtful quality of such translations under investigation may be due to the lack of translators' professionalism or the consequence of machine translation result which is usually far from adequate. Alongside with adequacy of translation translators' responsibility for the quality of translation is also considered to be important as advertising in tourism should be performed in accordance with certain criteria.

It's often not easy to achieve adequate and apt translation and this is due to the intercultural asymmetry being essential feature of touristic texts in different languages.

Intercultural asymmetry is often expressed by the so-called non-equivalents lexis due to categorization [9, p. 209]. Therefore, a translator or an interpreter should not only possess high competence of both source and target languages but also have profound background knowledge about the events described.

To avoid errors and irregularities in touristic discourse translation the strategy of re-addressing should be employed as the one allowing to minimize relevant information loss by selecting stylistically and lexically apt equivalents.

All these strategies may be applied to the translation of any type of discourse, however pragmatics and stylistics of advertising touristic texts is unique.

Among the peculiarities of touristic discourse there are stimulating, accessibility, personalization, high information value and expressiveness.

The principle of high information value is often foregrounded by many scholars in translating from English into Ukrainian, nevertheless, even more important there seems to be the audience's attraction.

In the course of the research there has been performed an overall linguistic analysis of English touristic texts and their Ukrainian translation.

The findings of the analysis are as follows:

- on the grammatical level: the prevalence of the Imperative Mood forms aimed at attracting customers, the use of finite tense verb forms to express the ideas of timelessness of travelling, season shift and to get the audience focus on attractiveness of certain sites and places, the use of the Passive Voice forms and complex nominative infinitive constructions to underline the absence of the direct connection between the addresser and the addressee;

- on the lexical level: pleonasm (the high frequency of lexical repetitions aimed at affecting the future tourists' minds, the employment of idioms, stylistically colored figures of speech and words with explicit positive evaluation;

- on the phonological level: use of assonance, alliteration, sound-imitation, rhyming and rhythm to add expressiveness to the discourse.

All the above mentioned features are characteristic of advertising texts with a powerful potential of manipulating techniques.

English advertising touristic texts for analysis have been selected from the universally known touristic site www.tripadvisor. co.uk. The overall selection of English advertising tourist texts under investigation comprised about 100 advertising tourist texts of different genres (tour descriptions, hotel/cruise information booklets, hotel brochures, excursion itineraries, travel guides, reservation requests). In this research advertising tourist texts are interpreted as finished speech products containing any tourismoriented information and aimed at distributing this information and promoting travel products via printed editions or Internet.

At the first stage of the research three kinds of advertising tourist texts were compared according to their information value or density. The lexical density was calculated by means of the open tool Textalyser according to Taylor's methodology [15, p. 38]. As for Ukrainian translations, their density was calculated by means of the open tool Advego. The calculation was made according to the formula

$$
\mathrm{Ld}=(\mathrm{Ndw} / \mathrm{Nw})^{*} 100 \text {, }
$$

where Ld was lexical density, Ndw - the number of notional words and $\mathrm{Nw}$ - the total number of all words used. Still another index was calculated - the terminological lexis density (Td). The findings of the research confirmed the dependence of the intensity 
of information value on the expectations of the target audience which varied in different language cultures (English and Ukrainian). At the second stage the corpuses of the both English and Ukrainian advertising tourist texts were analyzed by means of the open source corpus analyzer CATMA 4. The table 1 illustrates the percentage of density in English advertising tourist texts as contrasted to the Ukrainian ones.

Table 1

The percentage of general lexis density and terminological in English advertising tourist texts as contrasted to the Ukrainian ones in different genres, $\%$

\begin{tabular}{|c|c|c|c|c|}
\hline \multirow{2}{*}{ Genres } & \multicolumn{2}{|c|}{$\begin{array}{c}\text { English advertising tourist } \\
\text { texts }\end{array}$} & \multicolumn{2}{c|}{$\begin{array}{c}\text { Ukrainian advertising } \\
\text { tourist texts }\end{array}$} \\
\cline { 2 - 5 } & Ld & Td & Ld & Td \\
\hline Travel guides & 80,2 & 19,8 & 81,5 & 18,5 \\
\hline $\begin{array}{c}\text { Information } \\
\text { booklets }\end{array}$ & 69,5 & 30,5 & 70,7 & 29,3 \\
\hline $\begin{array}{c}\text { Excursion } \\
\text { itineraries }\end{array}$ & 75,3 & 24,7 & 73,2 & 26,8 \\
\hline $\begin{array}{c}\text { Reservation } \\
\text { requests }\end{array}$ & 64,4 & 35,6 & 65,2 & 34,8 \\
\hline
\end{tabular}

The interpretation of the research results have revealed that tourist texts oriented at people professionally employed in tourism field had a reasonably higher percentage of the terminological lexis density as compared to travel guides, information booklets and excursion itineraries. This was true for both English tourist texts under analysis and their Ukrainian translations.

All the terms were subdivided into six lexico-semantic groups according to their lexical semantics: 1) words denoting types of tourism; 2) names of occupations in the tourism field; 3) names for accommodation items; 4) vocabulary on catering; 5) vocabulary on transport means; 6) lexis on excursions and guided tours. According to the findings the tourist texts, created to convey the information between industry professionals, have proved to contain more terminology and less general lexis than those created for the purpose of convincing or informing tourists.

A lot of attention has been paid to the research of abbreviations in tourist texts, mainly their origin and functions. Among the abbreviations, initialisms in particular, which were distinguished as the most widely spread are the following: $B \& B$ (bed and breakfast), WATA (a global network of travel companies), VIP (very important person), WTM (World Travel Market), ALL-IN (all inclusive).

The subdivision of tourist terms into certain categories is rather vague as many of them are interchangeable between different lexicosemantic groups. For instance, full board or $B \& B$ can belong both to accommodation and catering groups, whereas reservation is the term, used in accommodation, catering and excursion groups. Moreover, abbreviations can be found in all groups of tourism terminology.

One of the possible and most recurrent challenges for translators and interpreters in travel industry field are cultural differences in concepts between tourism terms in target language and source language countries. Thus, standards for standard rooms vary between hotels of different countries or even hotels of one and the same country. Economy rooms in some countries offer shared facilities to their guests while economy rooms in other countries offer en suite facilities but have no balcony or are smaller in size. In some countries rooms are qualified as superior or even deluxe though they have the same facilities as the standard rooms in other parts of the world. There is no clear reference concerning bed size as well, therefore, some king-size beds are "more king-sized" than the other ones. Likewise, if there is an abbreviation $B \& B$ (or $A B F)$ in a hotel reservation confirmation, some hotels will offer their guests buffet-type breakfast with the wide selection of food while in other hotels the visitors will have set breakfast (e. g. some bacon-and-eggs with a toast, butter, jam and a cup of tea or coffee). Such discrepancies in general tourism concepts add more challenge to the question of standardization of tourism terminology to say nothing of translation itself.

The global nature of tourism is somehow reflected in the existing synonymy of tourist terms. For instance, terms American Plan (AP), full pension $(F P)$ and full board $(F B)$ mean that the price of the room includes three meals a day. Modified American Plan (MAP), half pension $(H P)$ and half board $(H B)$ mean that the room rate includes breakfast and either lunch or dinner. Terms tour manager, tour conductor, tour escort, tour leader, tour director, tour courier are used to name a person escorting tour group during the entire trip. At the same time, in Ukraine and Russia tour manager is used to denote a person, called tour agent or travel agent in other countries.

Most tourist terms are polysemantic, this is especially true for abbreviations (e. g. FIT is used to denote both free and independent traveler and foreign individual traveler; CTA means Canadian Tourism Alliance and Close to Arrival, AA can denominate American Airlines, Aerolineas Argentinas, Automobile Association, always afloat and apparent attitude and need context-based attention on translator's part).

Most troublesome and difficult objects of translation are acronyms, abbreviations which are pronounced solidly as words and often coincide in form with general lexis. This may be illustrated by the following example (e. g. any time ticket is non-refundable. changes not permitted. note - when combining on a half roundtrip basis the penalty conditions for each fare component apply. yq/yr charges are non-refundable. refund of unused taxes permitted for fully unused fare component. if part of fare component is used - in this case no tax refund will be permitted.name change permitted for a fee and upgrade. please contact bt for more details.1 - psgr p1 adt rules displayfare component; 2 adt pariev bt puath9 pu $1 \mathrm{~s} ; \mathrm{fcl}$ : puath9 trf: 21 rule: 5502 bk: p; ptc: adt-adult ftc: xpv-inst purch nonref 2 nd $l v l$ pe.penalties). This text contains many acronyms some of which make sense only to tourist professionals.

As far as translation operations are concerned the most widely used translation transformations employed in translating tourist texts are transliteration, transcription, calque translation, gloss translation or the combinations of the above mentioned. The search for translation equivalent and functional replacement are less frequent partly because of the phenomenon of "inexistence of terminology" (the term coined by a theoretician in translation M. Teresa Cabré) [9, p. 358].

As for the translation strategies, the most apt for translating tourist texts is the strategy of re-addressing presupposing the employment of the tactic of national and cultural adaptation due to the existing cross-cultural discrepancies between the source language and the target language audiences.

Conclusions. It has been concluded that the density of tourist texts fully correspondences with the degree of specialization of a text and makes its translation more complicated. The text, intended for tourism specialists can be completely vague and unclear for common tourists. 
Thus, the strategy of re-addressing and the tactic of national and cultural adaptation have proved to be most appropriate and efficient for translating tourist texts. The conclusion has been drawn that tourist texts with high level of term density should be neutralized to achieve high quality translation. As it follows, the quality of advertising tourist texts translation may be estimated on the grounding of the simplicity of the adapted translations as compared to the source texts. Particular attention should be paid to terms, both full and abbreviated.

The perspective is seen in working out methodological basis for the qualified translation of tourist texts of different types and genres. The possibility of creating the universal standards for translating tourism-oriented texts is also considered.

\section{References:}

1. Заюкова Е.В. К проблеме адекватного перевода туристического дискурса: сопоставительное исследование лингвокультурологических факторов перевода. Мир науки, культуры, образования. 2016. № 5(60). C. 335-337.

2. Королькова С.А., Новожилова А.А., Шейко А.М. Туристический дискурс: стратегии и проблемы перевода сайтов отелей. Becmник Волгоградского государственного университета. Серия 2 «Языкознание». 2017. Т. 16. № 3. С. 80-89.

3. Никитина Т.Г. Трудности перевода туристического текста. Кониеепт. 2019. № 4. С. 255-261.

4. Тюленева Н.А. Лингвокогнитивные стратегии позиционирования и продвижения туристических услуг в российской и англо-американской рекламе : автореф. дисс. ... канд. филол. наук. Екатеринбург, 2008. 19 с.

5. Филатова Н.В. Жанровое пространство туристического дискурса. Rheта. Рема. 2012. № 2. С. 76-82.

6. Цыремпилон А.О., Платицына Т.В. Принципы конструирования англоязычного туристического дискурса и переводческая практика. Филологические науки. Вопросы теории и практики. 2018. № 6(84). Ч. 1. С. 182-186.

7. Цыремпилон А.О., Цыренжапова Д.Х. Алгоритмизация перевода текстов туристического дискурса на английский язык. Филологические науки. Вопросы теории и практики. 2019. № 12(8). C. 279-282.

8. Юдина Т.А. К вопросу о безэквивалентной лексике и способах ее передачи при переводе (на примерах текстов туристического дискурса). Орловский государственный институт культуры как фундаментальный иентр сохранения и развития отечественной культуры : материалы Международной научно-практической конференции, г. Орел, 2 марта 2017 г. Орел, 2017. С. 207-210.

9. Cabré M.T. Terminology and Translation. Handbook of Translation Studies /Y. Gambier, L. van Doorslaer (eds.). Amsterdam : J. Benjamins Publishing Company, 2010. $100 \mathrm{p}$.
10. Dann G.M.S. The language of tourism: a sociolinguistic perspective. Wallingford: CAB International, 1996. $120 \mathrm{p}$.

11. Newmark P. Paragraphs on Translation. Adelaide : Multilingual Matters Ltd, 1993. $130 \mathrm{p}$.

12. Pierini P. Quality in web translation: an investigation into UK and Italian tourism web sites. The Journal of Specialized Translators. 2007. Vol. 8. P. 85-103.

13. Sanning H. Lost and Found in Translating Tourist Texts. Domesticating, Foreignising or Neutralising Approach. The Journal of Specialised Translation. 2010. Vol. 13. P. 124-137.

14. Taylor C. Language to Language. A practical and theoretical guide for Italian/English translators. Cambridge : Cambridge University Press, 1998. $150 \mathrm{p}$.

Юхимець С. Ю. Особливості перекладу українською англомовних рекламних текстів із туризму

Анотація. Статтю присвячено особливостям перекладу англомовних рекламних текстів із туризму порівняно 3 іншими видами реклами та іншими текстами. У роботі розкривається сутність туристичного дискурсу та визначаються відмінні характеристики туристичних текстів.

Результати дослідження свідчать про те, що туристичний дискурс $є$ підтипом дискурсу реклами внаслідок наявності певних типологічно спільних рис для неблизько споріднених англійської та української мов. 3-поміж цих характеристик виокремлюються такі: вживання дієслів у формі наказового способу, використання прикметників у вищому та найвищому ступенях порівняння, поширеність емоційно забарвлених слів із позитивною оцінною конотацією, що спрямовані на привернення уваги споживачів до послуг туристичної компанії. Зроблено висновок про пряму залежність складності перекладу від інформативної насиченості туристичних текстів. Текст, орієнтований на представників туристичної індустрії, може бути зовсім незрозумілим для пересічних туристів. Отже, це пояснює поширеність стратегії переадресації та тактики лінгвокультурної адаптації з метою нейтралізації під час перекладу текстів із високим рівнем інформативної насиченості. Загалом вбачається, що якість перекладу у сфері туризму здебільшого зумовлена перекладом туристичної термінології. Питання вивчення особливостей використання абревіатур в англомовних туристичних текстах та стратегій їх відтворення в перекладі неспорідненими мовами потребує додаткової уваги в подальших публікаціях.

У роботі представлено огляд засобів і способів перекладу туристичної термінології. Також наведено детальний аналіз стратегій, тактик та операцій перекладу англомовних рекламних туристичних текстів українською мовою. Перспектива вбачається у створенні універсальних стандартів для адекватного перекладу туристичного дискурсу.

Ключові слова: рекламні туристичні тексти, туристичний дискурс, стратегія, дистинктивні риси, термінологія. 